Article

\title{
Innovation Mode and Optimization Strategy of B2C E-Commerce Logistics Distribution under Big Data
}

\author{
Yingyan Zhao ${ }^{1}$, Yihong Zhou ${ }^{2}$ and Wu Deng ${ }^{3, *}$ \\ 1 College of Business Administration, Ningbo Polytechnic, Ningbo 315800, China; 1001566@nbpt.edu.cn \\ 2 Office of Educational Administration, Ningbo Polytechnic, Ningbo 315800, China; 0809075@nbpt.edu.cn \\ 3 School of Software Engineering, Dalian Jiaotong University, Dalian 116028, China \\ * Correspondence: dw7689@djtu.edu.cn
}

Received: 22 March 2020; Accepted: 18 April 2020; Published: 21 April 2020

check for updates

\begin{abstract}
With the advent of big data era and rapid development of Internet technology, e-commerce has had a strong development tendency that causes many problems, such as redundant and complex business processes, low efficiency and a high cost for e-commerce logistics in the distribution sector. It is not difficult to conclude that the key to improving logistics distribution efficiency-and reduce logistics distribution costs-is to optimize logistics distribution under big data. In this study, the management model, influence factors and development status of B2C e-commerce logistics distribution under big data are analyzed in detail. Then big data processing, business process and route optimization strategies for B2C e-commerce logistics distribution under big data are deeply studied. Furthermore, an optimization model of product sales and logistics distribution of B2C e-commerce by big data platform is discussed in order to propose an innovative optimization strategy for B2C e-commerce logistics distribution under big data. Big data technology is applied in B2C e-commerce logistics business management, which is studied in detail. These findings achieve the optimal distribution of B2C e-commerce, reduce the B2C e-commerce logistics distribution cost and improve the $\mathrm{B} 2 \mathrm{C}$ e-commerce logistics distribution efficiency under big data. In addition, enhanced competitiveness of B2C e-commerce logistics distribution is examined in this study. This study provides a reference for follow-up big data studies in the field of e-commerce.
\end{abstract}

Keywords: B2C e-commerce; logistics distribution; Big data; optimization strategy; innovative model

\section{Introduction}

Recently, with the rapid development of e-commerce in our country, the scale of e-commerce transactions continues to expand and the consumption means have also changed for people [1-3]. According to the Ministry of Commerce of the People's Republic of China, the e-commerce transaction volume has reached 4.48 trillion USD in 2018, which increased $8.5 \%$ year-on-year, the online sales reached 1.28 trillion USD, which increased $23.9 \%$ year-on-year [4-7]. The business volume of national logistics companies has reached 507.1 billion pieces, which increased $26.6 \%$ year-on-year. People employed in the e-commerce has reached 47 million, which increased $10.6 \%$ year-on-year. Therefore, the e-commerce has been playing an increasing role in daily lives. Currently, the e-commerce companies has three main distribution modes of in-house logistics distribution, third-party logistics distribution and the combination of the two modes.

With the coming of big data era, the relation between e-commerce and logistics distribution is strengthening over time. Logistics distribution becomes a key indicator in terms of evaluating the competitiveness of e-commerce companies [8-15]. Distribution mode directly determines the cost and the quality of logistics distribution of e-commerce companies, as well as the supply chain [16-20]. Logistics distribution of B2C e-commerce under big data has taking on the information concentration, 
sharing distribution resource and integration of data resources, etc. [21-27]. In recent years, a lot of researchers proposed logistics distribution models and methods for B2C e-commerce. Ran et al. [28] proposed a flexibility assessment method by adding cost weighted time. Jia [29] analyzed the distribution route method of traditional B2C model. Liu et al. [30] analyzed the capacity of terminal logistics distribution in Chinese cities. Zhang [31] proposed the optimization method of logistics distribution in online e-commerce. Leung et al. [32] proposed an intelligent system of B2C e-commerce for redesigning the e-order fulfilment process. Arnold et al. [33] demonstrated the effects of different delivery concepts. $\mathrm{Xu}$ et al. [34] proposed an e-commerce logistics operation risk quantitative analysis method based on a large number of e-commerce transaction data. Barenji et al. [35] proposed an e-commerce logistics park scheduling and synchronization method using mixed agents. Moons et al. [36] proposed an integrated order picking-vehicle routing method based on record-to-record travel algorithm. Olsson et al. [37] provided a more consistent view for the logistics research. Zhong et al. [38] proposed a distribution decision making method without cooperative mode. Zhou et al. [39] designed a B2C e-commerce management module. In addition, for logistics distribution, many researchers have proposed a lot of optimizations method to obtain the optimal logistics distribution schemes [40-53].

Through the above literatures, it can be found that the current domestic and foreign research mainly focuses on the basic research of logistics distribution mode, the revision and application of calculation model and the application research for solving a problem. However, there are still some deficiencies in the theoretical level of e-commerce logistics distribution under big data, which are mainly manifested as follows.

(1) The researchers lack an overall grasp of the development process of the B2C e-commerce logistics distribution under big data, which is lack clear guidance on the development direction of future related research.

(2) The basic elements, boundaries and theoretical basis of the B2C e-commerce logistics distribution under big data are not enough discussed. The deepening and development of $\mathrm{B} 2 \mathrm{C}$ e-commerce logistics distribution under big data are facing great challenges, so it is urgent to systematically sort out the research status of $\mathrm{B} 2 \mathrm{C}$ e-commerce logistics distribution under big data and give reasonable suggestions for future development direction under big data.

Therefore, how to improve the logistics distribution service efficiency of B2C e-commerce through analyzing and mining big data are the biggest challenge of B2C e-commerce logistics enterprises under big data. In this paper, for the deficiencies of the low efficiency and high cost of logistics distribution for B2C e-commerce under big data, the logistics distribution model, influence factors and development status of $\mathrm{B} 2 \mathrm{C}$ e-commerce under big data are analyzed. The data processing, business process and route optimization strategy of B2C e-commerce logistics distribution under big data are deeply studied. The joint optimization mode of B2C e-commerce between product sales and logistics distribution based on the big data platform are explored and discussed in order to propose the innovation optimization strategy of B2C e-commerce logistics distribution under big data, which can reduce the logistics distribution cost of B2C e-commerce, improve the efficiency B2C e-commerce logistics distribution. Finally, big data technology is applied in B2C e-commerce logistics business management in detail.

\section{Present Circumstance of B2C E-Commerce Logistics Distribution under Big Data}

By researching and analyzing many relevant literatures, the present circumstances of B2C e-commerce logistics distribution under big data are analyzed and summarized as follows.

\subsection{Low Efficiency of Logistics Distribution Data Processing}

Currently, big data technologies are only restricted to some specific services in the process of B2C e-commerce logistics distribution and lacks the integration analysis and processing of big data technology that can be effectively applied to all aspects of B2C e-commerce logistics distribution, which has become a bottleneck that hinders big data analysis and processing technology in B2C e-commerce logistics distribution. Therefore, from the overall view, we know that the actual utilization 
efficiency of analysis and processing technology under big data are inefficient, which needs to be further expanded. Big data analysis and processing technology still needs to be further improved.

\subsection{Lack of Innovation of Logistics Distribution Mode}

With the developing of big data technology for many years, many new big data technologies have been put forward and applied in various industries. It is essential for an early stage B2C e-commerce enterprise to recognize the importance of big data and improving its logistics distribution service level. In order to serve this purpose, the e-commerce enterprises ought to establish a complete application system with open or network characteristics under big data to realize the innovation of B2C e-commerce logistics distribution strategy and mode for improving the efficiency and B2C e-commerce logistics distribution service level to some extent. However, due to the serious impact of complex data on the strategy and mode, the internal architecture of the application system is affected by various cumbersome data processing, so it is unable to improve the contribution of $\mathrm{B} 2 \mathrm{C}$ e-commerce logistics distribution.

\subsection{Lack of Optimization of Logistics Distribution Process}

Logistics distribution center construction of B2C e-commerce reflects an enterprise's capabilities, it relies on choosing a good timing and location. The rationality of design and planning has a direct and far-reaching impact on the operation efficiency and safety of B2C e-commerce logistics distribution center, as well as the rationalization of logistics. The traditional logistics distribution center of B2C e-commerce has some problems, such as the inconsistency of the collecting phase and shelving phase, frictions of intake department and outbound department, long distance of running replenish. Therefore, the logistics distribution process of $\mathrm{B} 2 \mathrm{C}$ e-commerce is lack of optimization.

\subsection{A Huge Impact on B2C E-Commerce Logistics Distribution Enterprises under Big Data}

A large amount of data has been categorized and processed under big data, in order to make logistics distribution transparent, facilitate real-time monitoring of logistics distribution and meet the demand of B2C e-commerce logistics distribution. With the ever increasing of competitive market for the logistics distribution enterprises, the focus has been shifted from price competition to service based competition.

\subsection{Low Efficiency of the Third-Party Logistics Distribution}

A lot of enterprises have chosen third-party logistics enterprises under big data. Third-party logistics is that e-commerce enterprises outsourced their logistics business to the outside logistics enterprises, which have their own logistics management platform and able to monitor and manage products and logistics information. The e-commerce enterprises choose the third-party enterprise logistics distribution, which can not only improve the level and efficiency of e-commerce enterprises' logistics distribution, but also help to improve consumer satisfaction. However, due to the influence of many factors such as infrastructure, human quality, etc., the logistics distribution efficiency of B2C e-commerce is low.

\subsection{Low Level of Logistics Standardization System}

To make the logistics business efficient, on the one hand, it is necessary to standardize the means of transport, including containers, pallets, trucks, shelves, etc. On the other hand, there is necessary to standardize the logistics information system. That is, all links in the supply chain should use the same standard and all logistics information systems can be connected, exchange data and share information. 


\section{Influence Factors and Core Problem for B2C E-Commerce Logistics Distribution under Big Data}

According to the current situation, the low efficiency, low innovation and low efficiency are that big data of B2C e-commerce and logistics are independent and separated in the current industrial development process [53-58]. Therefore, in order to accelerate the division of labor, coordination, integration, communication and interrelationship between the two industries and generate cooperative effect, there is necessary to implement the development of big data technology. At present, the industry chain as a whole has rapid response to changes in market demand and operational efficiency.

\subsection{Realize the Information Docking of B2C E-Commerce Logistics Distribution}

With the ascent of big data, B2C e-commerce has been growing rapidly, which caused increasingly heavy logistics and distribution and logistics distribution data increased exponentially. It will burden the e-commerce enterprises if those voluminous data are deal with by using traditional acquisition and processing methods for information. Big data processing method is used to deal with all kinds of logistics information, which can effectively promote the logistics distribution of B2C e-commerce and meet logistics requirements.

\subsection{Increase the Logistics Distribution Utilization Value of B2C E-Commerce}

With the rapid developing of B2C e-commerce, many data are produced in e-commerce logistics distribution. To make full use of the value of these data, there is necessary to transform big data to the structural data sets. The data structure transformation of traditional B2C e-commerce logistics distribution will lead to lose logistics information and reduce the utilization value of logistics distribution data. Under big data, a special data management center is established in order to avoid information loss and promote the utilization value of B2C e-commerce logistics distribution data.

\subsection{Improve Customer Satisfaction of B2C E-Commerce Enterprises}

With the continuous development of B2C e-commerce enterprises, the development of big data technology can improve customer satisfaction. Improving the service level of B2C e-commerce enterprises is an effective method. In the traditional logistics distribution of B2C e-commerce, its service level improvement space is limited. However, under big data, we can use artificial intelligence and data mining methods to analyze and mine the online shopping big data of customers, which can help $\mathrm{B} 2 \mathrm{C}$ e-commerce enterprises to personalize the logistics distribution of B2C e-commerce, thus improve the customer satisfaction.

\subsection{Interaction with Sustainable Development Goals of B2C E-Commerce Logistics Distribution}

(1) The development of B2C e-commerce can faster and more effectively promote and promote the development of the logistics industry and the improvement of the logistics system, especially for the logistics distribution industry. It needs the distribution of comprehensive material resources, which can promote the growth of the comprehensive logistics providers.

(2) The development of B2C e-commerce can expand the logistics space-the second space of logistics, that is, E-logistics, which will be the opposite bank of the logistics development. The first space of logistics and the second space of logistics will be increasingly integrated.

(3) The development of B2C e-commerce can promote logistics informatization. B2C e-commerce must be based on informatization. Logistics informatization includes at least three levels. They are the national and regional logistics enterprise construction, logistics enterprise informatization and enterprise logistics informatization. The key point is distribution enterprise informatization, which will inevitably drive the whole logistics informatization and comprehensively improve the level of logistics informatization. 
(4) The development of B2C e-commerce can greatly promote the integration of logistics and business flow, which is an important feature of the development of modern logistics and an important guarantee for the success of distribution. In the process of online transaction and logistics distribution, the boundary between logistics and business flow will be increasingly weakened and blurred. The customers and demands of B2C e-commerce are increasingly diversified.

(5) The development of B2C e-commerce will promote the application of logistics technologies. B2C e-commerce pays attention to speed and synchronous distribution ability. To adapt to these two points, it is necessary to adopt modern logistics technologies, especially for various technologies in distribution, such as barcode technology, radio frequency technology, EDI, information technology and network technology. The logistics distribution must also use IT technologies.

\section{Model of B2C E-Commerce Logistics Distribution under Big Data}

Big data are the large-scale data collection that cannot be acquired, stored, managed and analyzed by database software tools $[59,60]$. It has four characteristics of high data volume, rapid data flow (velocity), diverse data types and low value density. With the developing information technology, the Internet technologies of cloud computing, Internet of things and social networks were widely applied in people's study, daily lives and works. Variety of data are increasing exponentially. According to the report of International Data Corporation (IDC), the global data volume is doubled annually and the volume will increase to $175 \mathrm{ZB}$ in 2025. China will become the biggest data processor in the world, data volume will increase to $48.6 \mathrm{ZB}$, accounting for $27.8 \%$ of the global data [61,62].

Big data contains valuable information and knowledge. These data are analyzed and mined, which can help enterprises better perform its service to customers and reduce cost, reasonably allocate resources in order to bring innovative business model and management skills [63,64]. The idea of building logistics distribution management model of $\mathrm{B} 2 \mathrm{C}$ e-commerce under big data are given. In the stage of data collection, B2C e-commerce enterprises, logistics enterprises and terminal customers are integrated through the data sources in the industrial chain. Then these data are mined, analyzed and extracted to promote the transformation of data from unstructured data to structured data by using big data technologies, so as to better reflect he law of data. The goal is to improve the data value and used value, and ultimately, achieve personalized and high-quality services to obtain more customers. The design is just the embodiment of solving the core problems in the front. The management model of B2C e-commerce logistics distribution under big data are shown in Figure 1.

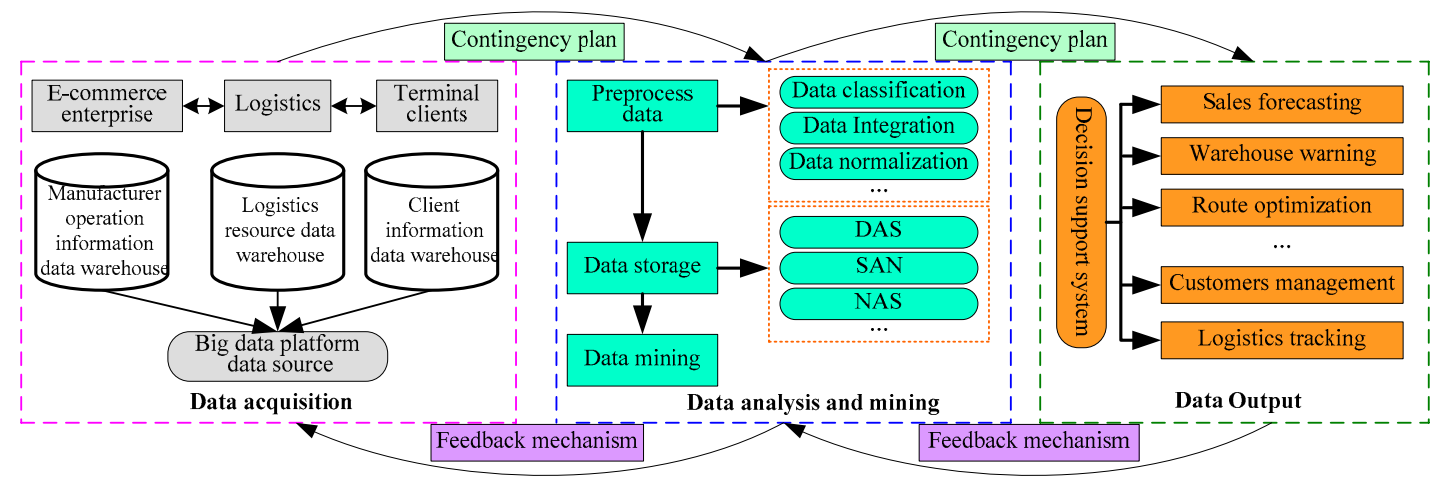

Figure 1. The management model of B2C e-commerce logistics distribution under big data.

This model consists of data acquisition, data preprocessing, data storage, data analysis and data mining. By analyzing and mining the data, it produces information, procedure, function, knowledge, feedback and backup plans for costumers in different application platform. It can further reconstruct the elements and business procedure, which advanced the development. 


\section{Innovation and Optimization Strategy for B2C E-Commerce Logistics Distribution under Big Data}

Based on the logistics distribution development of B2C e-commerce under big data, the analysis and processing technologies of big data in $\mathrm{B} 2 \mathrm{C}$ e-commerce logistics distribution strategy and mode is relatively single, the processing efficiency of data are low, the distribution process is lack of optimization and the distribution efficiency is low to be improved constantly. Therefore, in the overall development of B2C e-commerce logistics distribution, to promote the full application of big data analysis and processing technology to the logistics distribution development of $\mathrm{B} 2 \mathrm{C} \mathrm{e-commerce,} \mathrm{and} \mathrm{promote} \mathrm{the}$ full play of its value, we can effectively optimize and improve it from the following aspects.

\subsection{Optimization Strategy for B2C E-Commerce Logistics Distribution under Big Data Framework}

According to the low efficiency and universality problem in the current stage of B2C e-commerce logistics distribution under big data, it is essential to design and construct a complete optimization strategy under big data framework and optimize the value of B2C e-commerce logistics distribution. Therefore, on the basis of the original big data processing framework, drawing on the advanced experience, big data processing optimization strategy for B2C e-commerce logistics distribution based on the logistics distribution needs and characteristics of B2C e-commerce is discussed to propose an effective big data processing and optimization strategy based on COHadoop, namely ECLHadoop. Then a complete and mature big data processing optimization strategy framework of ECLHadoop is designed for logistics distribution of $\mathrm{B} 2 \mathrm{C}$ e-commerce. Big data processing framework of COHadoop is shown in Figure 2.

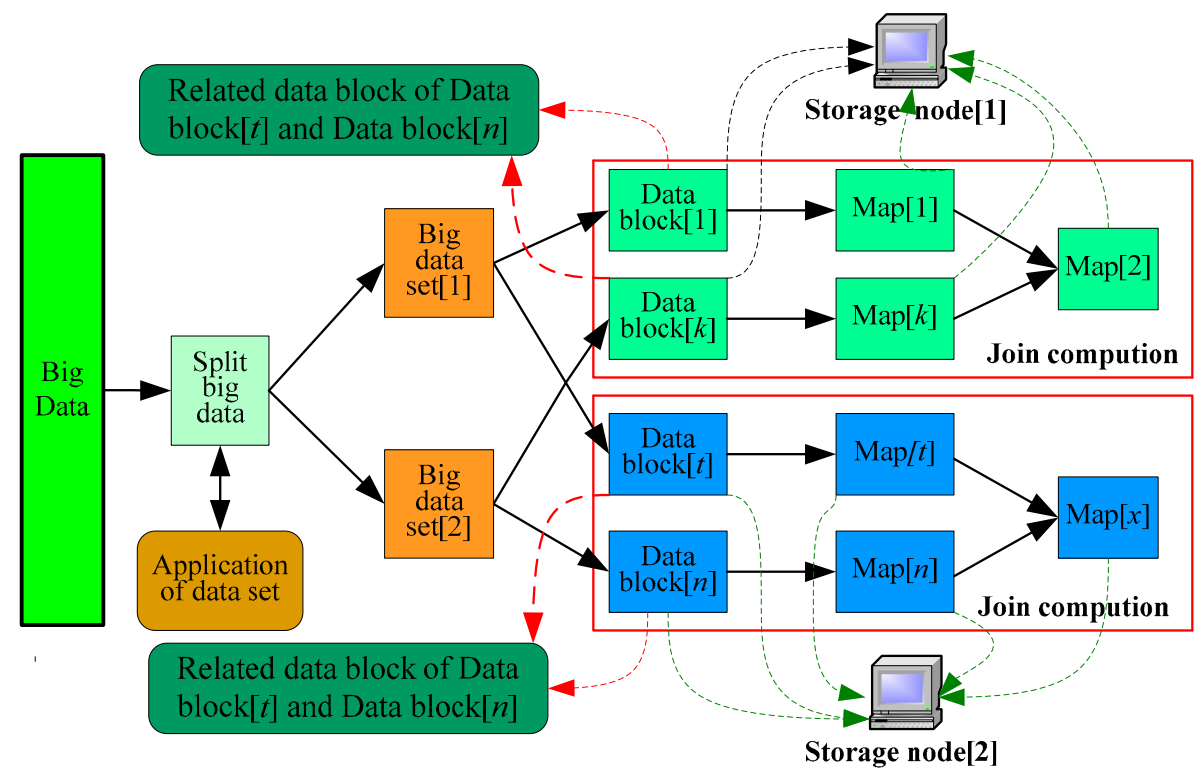

Figure 2. Big data processing framework of $\mathrm{COHadoop.}$

Big data optimization strategy framework of ECLHadoop is shown in Figure 3. 


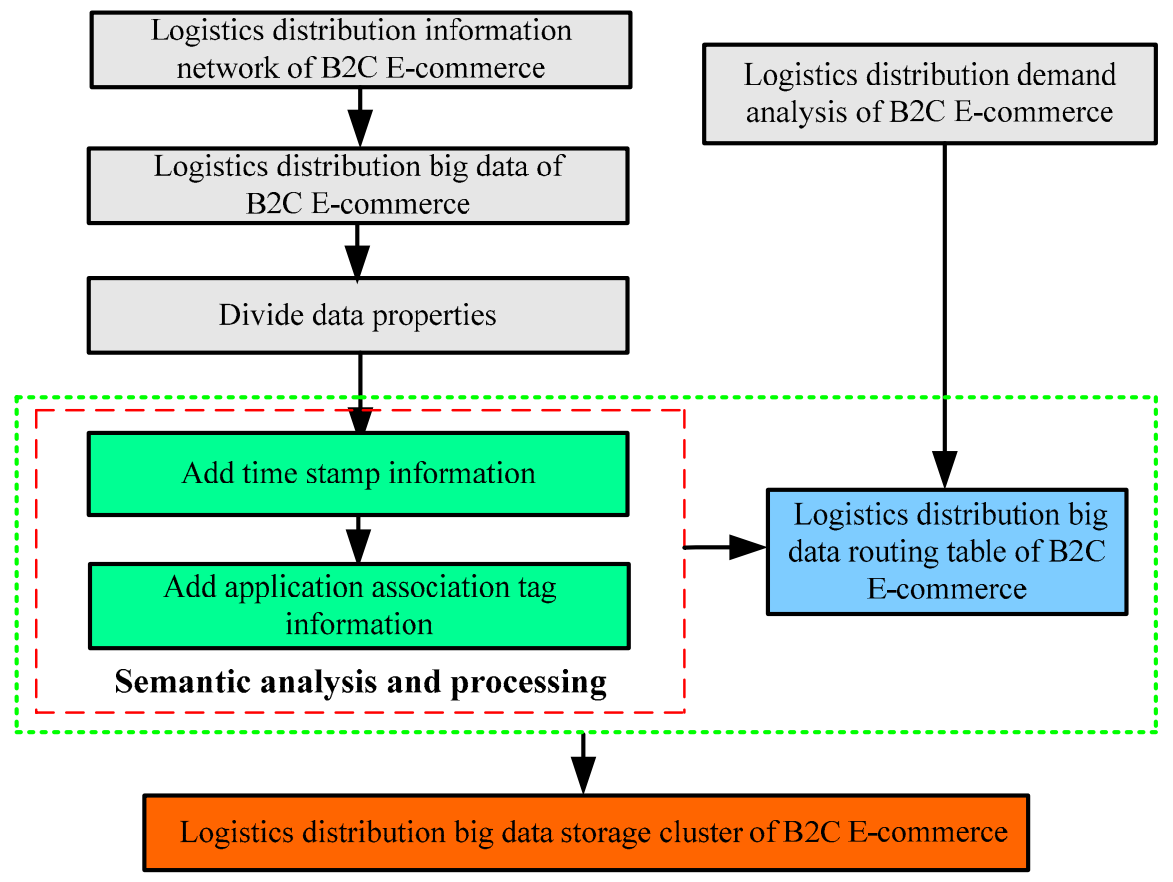

Figure 3. Big data processing framework of ECLHadoop with optimization strategy.

The framework is categorized data attributes according to the request of $\mathrm{B} 2 \mathrm{C}$ e-commerce logistics distribution, then the related data segmented, which are stored in data nodes. When it needs to be queried, one storage node is directly queried. MapReduce calculating is conducted by Map calculation, skipping Reduce calculation, in this way, the processing efficiency is improved, and the cost is reduced.

In addition, according to the relationship between data modules, the corresponding time tag and other methods are used to effectively link different data blocks, realize big data analysis and processing, and promote the effective acquisition of $\mathrm{B} 2 \mathrm{C}$ e-commerce logistics distribution information to improve its work efficiency, and provide a reference for developing logistics distribution field under big data.

\subsection{Hybrid Optimization Mode for B2C E-Commerce Product Sales and Logistics Distribution under Big Data Platform}

Even though B2C e-commerce logistics distribution has been developed rapidly, B2C e-commerce platform has become the main venue for consumption, the social logistics resources are not enough, and the logistics distribution capacity is poor in China. There is a disconnection between B2C e-commerce enterprise sales and logistics distribution. Customer satisfaction cannot be improved if information of goods purchased is unknown and door to door delivery and installment service are not delivered. Therefore, it is necessary to realize the joint optimization mode of B2C e-commerce product sales and logistics distribution based on big data platform. This mode is to connect the information generated in the process of logistics distribution with the commodity sales information of B2C e-commerce enterprises, improve the service level of logistics distribution through the joint optimization of the two kinds of information, so as to promote the logistics distribution development of B2C e-commerce. The successful cases are Cainiao Logistics, JD.com and Yuci Logistics, which realized the joint optimization mode of product sales and logistics distribution and effectively improved its service level.

\subsection{Optimization Strategy for B2C E-Commerce Logistics Distribution Process under System Layout Design}

According to the actual business process conditions of $\mathrm{B} 2 \mathrm{C}$ e-commerce logistics distribution, we will optimize and modify distribution business process. System layout design is to provide a complete, systematic and orderly layout design method to solve the facility layout problem. Based on 
the analysis of the operation intensity of each functional area and the correlation between the operation units, it can arrange the operation location reasonably. Through the qualitative and quantitative analysis, the relative position of functional areas is obtained by using five basic elements of $\mathrm{P}$ (product), $\mathrm{Q}$ (quality), $\mathrm{R}$ (route), $\mathrm{S}$ (service) and $\mathrm{T}$ (time) as the starting point of layout design analysis. Through the $\mathrm{P}-\mathrm{Q}$ analysis is used to choose the appropriate layout form. The logistics analysis is used to verify the necessity and rationality of the workflow and further improve it. The interaction between the work units is used to achieve the optimal combination of the layout plan. The continuous correction and selection is used to obtain the most economic and reasonable plan. The optimization process of B2C e-commerce logistics distribution based on system layout design is shown in Figure 4.

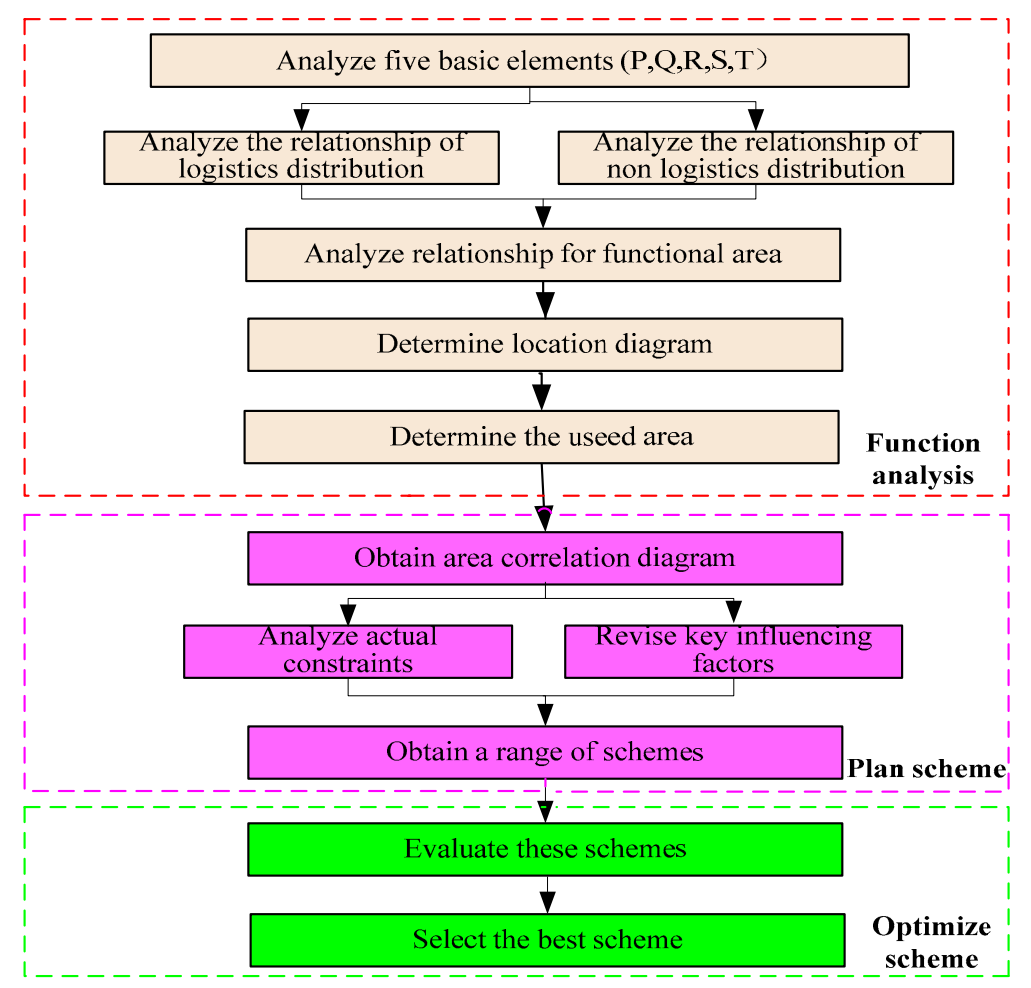

Figure 4. The logistics distribution process optimization flow of B2C e-commerce under system layout design.

\subsection{The Logistics Distribution Route Optimization of B2C E-Commerce under Big Data}

In the logistics distribution process of traditional B2C e-commerce, the stuffs make the corresponding logistics distribution decisions according to their own experience or market analysis results. Due to the lagged results of market analysis and subjective experience of stuffs, traditional B2C e-commerce logistics distribution decision is generally subjective and lagging behind. Then the massive data generated is objective and real-time, which can truly and effectively reflect the needs of the market and customers. Therefore, the logistics distribution enterprises must use this big data information, deeply analyze the influence factors of B2C e-commerce logistics distribution process route. The quantitative analysis method is applied to classify and simplify the influencing factors, determine the key factors that affect B2C e-commerce logistics distribution route. On this basis, the B2C e-commerce logistics distribution route is scientifically, reasonably and efficiently planned to reduce the cost of B2C e-commerce logistics distribution, improve the efficiency of B2C e-commerce logistics distribution, effectively solve the slow logistics distribution caused by traffic congestion, and realize the sustainable and rapid development of B2C e-commerce. 


\section{Big Data Technology in B2C E-Commerce Logistics Business Management}

Big data technology is applied in B2C e-commerce logistics business management is mainly reflected three core businesses of transportation business management, warehousing business management and distribution business management. The application of big data can realize the intelligent transportation of logistics distribution and optimize the allocation of transportation resources, realize the automation of warehousing business management and improve the service level of warehousing logistics, realize the dynamic control of logistics distribution, so as to improve the efficiency of logistics distribution and provide customers with dynamic and diversified logistics distribution services. Big data technology in B2C e-commerce logistics business management is shown in Figure 5.

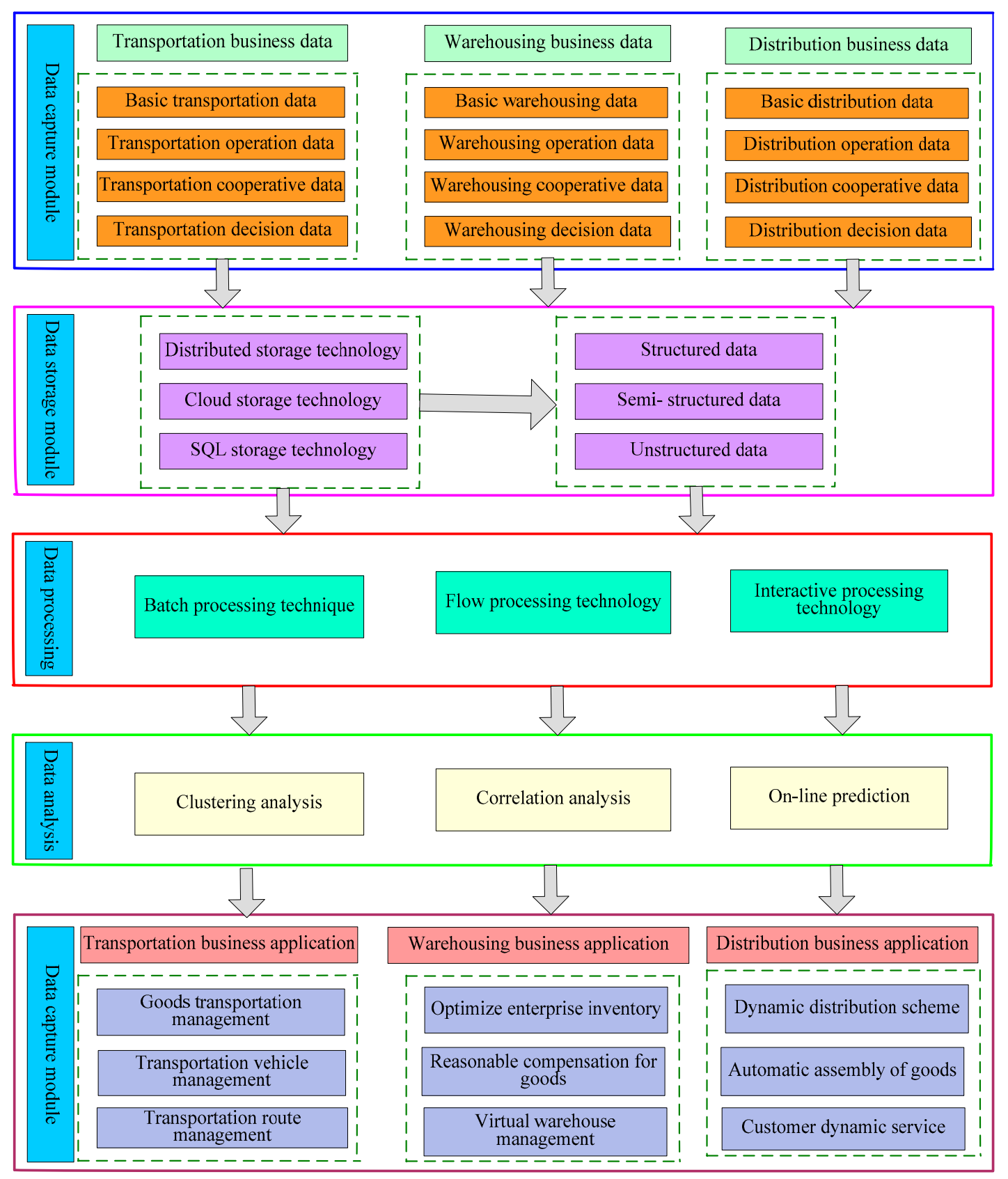

Figure 5. The application of big data technology in B2C e-commerce logistics business management. 
In the transportation business management, big data technology is applied to process and analyze the generated data in the transportation process, which can optimize the allocation of transportation resources, and realize the informatization and intelligent management and control of the transportation process. In the warehousing business management, big data technology can guide the warehouse to prepare goods, realize the refined inventory management and improve the prediction accuracy. It can effectively reduce the cost of storage, realize the visual and transparent management of the storage logistics. In the logistics distribution business management, big data technology can collect and mine the data of traffic conditions, price factors, customers quantity and distribution, customers demand and other factors, in order form a dynamic logistics distribution scheme, so as to provide real-time state information service of logistics distribution for customers for improving the logistics distribution efficiency and service quality.

\section{Conclusions and Contribution}

Big data has been an influential contributing factor for B2C e-commerce logistics distribution. It not only can promote the optimization of $\mathrm{B} 2 \mathrm{C}$ e-commerce logistics distribution process, but also can become the strategic resources and profit sources of B2C e-commerce logistics distribution enterprises. In $\mathrm{B} 2 \mathrm{C}$ e-commerce logistics distribution, the logistics distribution management model under big data has been constructed, the optimization strategy of big data processing in $\mathrm{B} 2 \mathrm{C}$ e-commerce logistics distribution is proposed in this paper. The joint optimization of $\mathrm{B} 2 \mathrm{C}$ e-commerce commodity sales and logistics distribution is promoted and the optimization process and route of $\mathrm{B} 2 \mathrm{C}$ e-commerce logistics distribution is proposed by using big data, which can facilitate the development of logistics enterprises and reduce the cost of B2C e-commerce logistics distribution, improved efficiency and service quality of logistics enterprises and enhance the competitiveness, which further promote the economy development.

The contributions of this paper include as follows.

(1) The research status and development status of B2C e-commerce logistics distribution under big data and the core problem of big data for solving logistics distribution problem of $\mathrm{B} 2 \mathrm{C}$ e-commerce are deeply discussed, which is the external manifestation of the theoretical extension and practical urgent need of big data technology in the business field.

(2) The logistics distribution management model of B2C e-commerce under big data are constructed. The three main bodies of e-commerce, logistics and customers are organically and integrally integrated into a management system from the perspective of coordination theory. At the same time, it also provides some useful ideas for further expanding these theories.

(3) The model is designed and optimized from the realization route of effective resource allocation, including big data processing framework, sales and distribution joint, distribution process and distribution route. This detailed study based on the construction of Chinese local context provides a reference for the follow-up research of $\mathrm{B} 2 \mathrm{C}$ e-commerce under big data.

(4) Application of big data technology in B2C e-commerce logistics business management is discussed in detail. It big data technology can collect and mine the data of traffic conditions, price factors, customers quantity and distribution, customers demand and other factors, in order form a dynamic logistics distribution scheme, so as to provide real-time state information service of logistics distribution for customers, so as to improve the efficiency of logistics distribution and service quality.

Author Contributions: Methodology, Y.Z. (Yingyan Zhao); investigation, Y.Z. (Yihong Zhou); resources, W.D.; data curation, Y.Z. (Yingyan Zhao); writing - original draft preparation, Y.Z. (Yingyan Zhao) and Y.Z. (Yihong Zhou); writing-review and editing, W.D.; funding acquisition, W.D. All authors have read and agreed to the published version of the manuscript.

Funding: This research was funded by the National Natural Science Foundation of China, Grant Number 61771087, Grant Number 51605068.

Conflicts of Interest: The authors declare no conflict of interest. 


\section{References}

1. Giuffrida, M.; Mangiaracina, R.; Perego, A.; Tumino, A. Cross-border B2C E-commerce to China An evaluation of different logistics solutions under uncertainty. Int. J. Phys. Distrib. Logist. Manag. 2019. [CrossRef]

2. Wang, X.T.; Wang, H. A study on sustaining corporate innovation with E-commerce in China. Sustainability 2019, 11, 6604. [CrossRef]

3. Yu, Y.N.N.; Kim, H.S. Online retailers' return policy and prefactual thinking An exploratory study of USA and China E-commerce markets. J. Fash. Mark. Manag. 2019, 23, 504-518. [CrossRef]

4. Department of Trade in Services and Commercial Services of the Ministry of Commerce Comments on China's Culture Trade in 2019. Available online: http:/english.mofcom.gov.cn/article/newsrelease/policyreleasing/ 202003/20200302946575.shtml (accessed on 1 January 2020).

5. Li, L.; Du, K.; Zhang, W.; Mao, J.-Y. Poverty alleviation through government-led E-commerce development in rural China: An activity theory perspective. Inf. Syst. J. 2019, 29, 914-952. [CrossRef]

6. Ranieri, L.; Digiesi, S.; Silvestri, B.; Roccotelli, M. A review of last mile logistics innovations in an externalities cost reduction vision. Sustainability 2018, 10, 782. [CrossRef]

7. Stefanini, A.; Aloini, D.; Benevento, E.; Dulmin, R.; Mininno, V. A data-driven methodology for supporting resource planning of health services. Socio-Econ. Plan. Sci. 2019, 100744. [CrossRef]

8. Aloini, D.; Benevento, E.; Stefaninia, A. Conceptual design of a tool supporting the last mile logistics in hospitals. In Proceedings of the 12th IADIS International Conference Information Systems, Utrecht, The Netherlands, 11-13 April 2019; pp. 245-249.

9. Fanti, M.P.; Rinaldi, A.; Roccotelli, M.; Silvestri, B.; Porru, S.; Pani, F.E. Software requirements and use cases for electric light vehicles management. In Proceedings of the 2018 IEEE International Conference on Systems, Man, and Cybernetics (SMC), Miyazaki, Japan, 7-10 October 2018; pp. 311-316.

10. Digiesi, S.; Fanti, M.P.; Mummolo, G.; Silvestri, B. Externalities Reduction Strategies in Last Mile Logistics: A Review. In Proceedings of the 2017 IEEE International Conference on Service Operations and Logistics, and Informatics (SOLI), Bari, Italy, 18-20 September 2017; pp. 248-253.

11. Liu, Y.; Mu, Y.; Chen, K. Daily activity feature selection in smart homes based on pearson correlation coefficient. Neural Process. Lett. 2020, 1-17. [CrossRef]

12. Wang, Z.; Ren, X.; Ji, Z.; Huang, W.; Wu, T. A novel bio-heuristic computing algorithm to solve the capacitated vehicle routing problem based on Adleman-Lipton model. Biosystems 2019, 184, 103997. [CrossRef] [PubMed]

13. Zhao, H.; Li, D.; Yang, X.; Deng, W. Research on vibration suppression method of alternating current motor based on fractional order control strategy. Proc. Inst. Mech. Eng. Part E J. Process. Mech. Eng. 2017, 231, 786-799. [CrossRef]

14. Deng, W.; Liu, H.; Xu, J.; Zhao, H.; Song, Y. An improved quantum-inspired differential evolution algorithm for deep belief network. IEEE Trans. Instrum. Meas. 2020. [CrossRef]

15. He, Z.; Shao, H.; Zhang, X.; Cheng, J.; Yang, Y. Improved deep transfer auto-encoder for fault diagnosis of gearbox under variable working conditions with small training samples. IEEE Access 2019, 7, 115368-115377. [CrossRef]

16. Ji, S.; Sun, Q. Low-carbon planning and design in b\&r logistics service: A case study of an E-commerce big data platform in China. Sustainability 2017, 9, 2052.

17. Wang, Y.; Wang, Y.; Lee, S.H. The effect of cross-border E-commerce on china's international trade: An empirical study based on transaction cost analysis. Sustainability 2017, 9, 2028. [CrossRef]

18. Zhao, H.; Zuo, S.; Hou, M.; Liu, W.; Yu, L.; Yang, X.; Deng, W. A novel adaptive signal processing method based on enhanced empirical wavelet transform technology. Sensors 2018, 18, 3323. [CrossRef]

19. Luo, J.; Chen, H.; Heidari, A.A.; Xu, Y.; Zhang, Q.; Li, C. Multi-strategy boosted mutative whale-inspired optimization approaches. Appl. Math. Model. 2019, 73, 109-123. [CrossRef]

20. Liu, Y.Q.; Wang, X.X.; Zhai, Z.G. Timely daily activity recognition from headmost sensor events. ISA Trans. 2019, 94, 379-390. [CrossRef] [PubMed]

21. Zhao, H.; Zheng, J.; Deng, W.; Song, Y. Semi-supervised broad learning system based on manifold regularization and broad network. IEEE Trans. Circuits Syst. I 2020, 67, 983-994. [CrossRef]

22. Su, W.; Wang, Y.; Qian, L.; Zeng, S.; Baležentis, T.; Štreimikienè, D. Creating a sustainable policy framework for cross-border E-commerce in China. Sustainability 2019, 11, 943. [CrossRef] 
23. Xu, Y.; Chen, H.; Heidari, A.A. An efficient chaotic mutative moth-flame-inspired optimizer for global optimization tasks. Expert Syst. Appl. 2019, 129, 135-155. [CrossRef]

24. Deng, W.; Li, W.; Yang, X. A novel hybrid optimization algorithm of computational intelligence techniques for highway passenger volume prediction. Expert Syst. Appl. 2011, 38, 4198-4205. [CrossRef]

25. Li, T.; Qian, Z.; He, T. Short-term load forecasting with improved CEEMDAN and GWO-based multiple kernel ELM. Complexity 2020, 2020, 1-20. [CrossRef]

26. Farooq, Q.; Fu, P.; Hao, Y.; Jonathan, T.; Zhang, Y. A review of management and importance of E-commerce implementation in service delivery of private express enterprises of China. SAGE Open 2019, 9, 2158244018824194. [CrossRef]

27. Li, T.; Shi, J.; Li, X. Image encryption based on pixel-level diffusion with dynamic filtering and DNA-level permutation with 3D Latin cubes. Entropy 2019, 21, 319. [CrossRef]

28. Ran, W.X.; Zhang, Z.; Liu, S. A flexible logistics distribution hub model considering cost weighted time. Discret. Dyn. Nat. Soc. 2017, 2017, 1-9. [CrossRef]

29. Jia, X.Y. Analysis and research on B2C model of agricultural product logistics distribution under electronic commerce mode. Agro Food Ind. Hi-Tech 2017, 28, 1122-1126.

30. Liu, H.Q.; Pretorius, L.; Jiang, D.D. Optimization of cold chain logistics distribution network terminal. EURASIP. J. Wirel. Commun. Netw. 2018, 2018, 158. [CrossRef]

31. Zhang, Q. Pharmaceutical management of linezolid and optimization of logistics distribution in online medicine E-commerce. Bol. De Malariol. Y Salud Ambient. 2018, 58, 35-43.

32. Leung, K.; Choy, K.L.T.; Siu, P.K.; Ho, G.T.S.; Lam, H.; Lee, C.K.M. A B2C E-commerce intelligent system for re-engineering the e-order fulfilment process. Expert Syst. Appl. 2018, 91, 386-401. [CrossRef]

33. Arnold, F.; Cardenas, I.; Sörensen, K.; Dewulf, W. Simulation of B2C E-commerce distribution in Antwerp using cargo bikes and delivery points. Eur. Trans. Res. Rev. 2018, 10, 2. [CrossRef]

34. Xu, G.; Qiu, X.; Fang, M.; Kou, X.; Yu, Y. Data-driven operational risk analysis in E-commerce Logistics. Adv. Eng. Informatics 2019, 40, 29-35. [CrossRef]

35. Barenji, A.V.; Wang, W.; Li, Z.; Guerra-Zubiaga, D.A. Intelligent E-commerce logistics platform using hybrid agent based approach. Transp. Res. Part E-Logi. Transp. Rev. 2019, 126, 15-31. [CrossRef]

36. Moons, S.; Braekers, K.; Ramaekers, K.; Caris, A.; Arda, Y. The value of integrating order picking and vehicle routing decisions in a B2C E-commerce environment. Int. J. Prod. Res. 2019, 57, 6405-6423. [CrossRef]

37. Olsson, J.; Hellstrom, D.; Palsson, H. Framework of last mile logistics research: A systematic review of the literature. Sustainability 2019, 11, 7131. [CrossRef]

38. Zhong, Y.; Guo, F.; Wang, Z.; Tang, H. Coordination analysis of revenue sharing in E-commerce logistics service supply chain with cooperative distribution. SAGE Open 2019, 9, 2158244019870536. [CrossRef]

39. Zhou, Q.Y.; Zhang, Z.M.; Wang, Y.C. Research on safety management system optimization of B2C E-commerce intelligent logistics information system based on data cube. J. Intell. Fuzzy Syst. 2020, 38, 1585-1592. [CrossRef]

40. Xu, Y.; Chen, H.; Luo, J. Enhanced Moth-flame optimizer with mutation strategy for global optimization. Inf. Sci. 2019, 492, 181-203. [CrossRef]

41. Zhao, H.; Liu, H.; Xu, J.; Deng, W. Performance prediction using high-order differential mathematical morphology gradient spectrum entropy and extreme learning machine. IEEE Trans. Instrum. Meas. 2019. [CrossRef]

42. Shao, H.; Cheng, J.; Jiang, H.; Yang, Y.; Wu, Z. Enhanced deep gated recurrent unit and complex wavelet packet energy moment entropy for early fault prognosis of bearing. Knowl. Based Syst. 2019, 188, 105022. [CrossRef]

43. Fu, H.L.; Wang, M.M.; Li, P. Tracing knowledge development trajectories of the internet of things domain: A main path analysis. IEEE Trans. Ind. Inf. 2019, 15, 6531-6540. [CrossRef]

44. Wang, Z.; Ji, Z.; Wang, X.; Wu, T.; Huang, W. A new parallel DNA algorithm to solve the task scheduling problem based on inspired computational model. BioSystems 2017, 162, 59-65. [CrossRef]

45. Chen, H.; Zhang, Q.; Luo, J. An enhanced Bacterial Foraging Optimization and its application for training kernel extreme learning machine. Appl. Soft Comput. 2020, 86, 105884. [CrossRef]

46. Xue, Y.; Xue, B.; Zhang, M. Self-adaptive particle swarm optimization for large-scale feature selection in classification. ACM Trans. Knowl. Discov. Data 2019, 13, 50. [CrossRef] 
47. Deng, W.; Xu, J.; Song, Y.; Zhao, H. An effective improved co-evolution ant colony optimization algorithm with multi-strategies and its application. Int. J. Bio-Inspired Comput. 2019, 2019, 1-10.

48. Deng, W.; Xu, J.; Zhao, H. An improved ant colony optimization algorithm based on hybrid strategies for scheduling problem. IEEE Access 2019, 7, 20281-20292. [CrossRef]

49. Deng, W.; Zhao, H.; Yang, X.; Xiong, J.; Sun, M.; Li, B. Study on an improved adaptive PSO algorithm for solving multi-objective gate assignment. Appl. Soft Comput. 2017, 59, 288-302. [CrossRef]

50. Chen, R.; Guo, S.K.; Wang, X.Z.; Zhang, T.L. Fusion of multi-RSMOTE with fuzzy integral to classify bug reports with an imbalanced distribution. IEEE Trans. Fuzzy Syst. 2019, 27, 2406-2420. [CrossRef]

51. Deng, W.; Zhao, H.M.; Zou, L.; Li, G.; Yang, X.; Wu, D. A novel collaborative optimization algorithm in solving complex optimization problems. Soft Comput. 2017, 21, 4387-4398. [CrossRef]

52. Yang, H.; Gong, S.S.; Liu, Y.Q.; Lin, Z.K.; Qu, Y. A multi-task learning model for daily activity forecast in smart home. Sensors 2020, 20, 1933. [CrossRef]

53. Gan, M.; Yang, S.; Li, D.D. A novel intensive distribution logistics network design and profit allocation problem considering sharing economy. Complexity 2018, 2018,1-15. [CrossRef]

54. Wang, Y.J. Negotiation and scheduling decisions of marine intelligent supply chain based on stochastic distribution. J. Coast. Res. 2019, 98, 183-186. [CrossRef]

55. Ouyang, F. Construction of integrated management model of port logistics supply chain based on big data. J. Coast. Res. 2019, 93, 1053-1058. [CrossRef]

56. Zhao, H.; Zheng, J.; Xu, J.; Deng, W. Fault diagnosis method based on principal component analysis and broad learning system. IEEE Access 2019, 7, 99263-99272. [CrossRef]

57. Cui, Y.L.; Xie, X.; Liu, Y. Social media and mobility landscape: Uncovering spatial patterns of urban human mobility with multi source data. Front. Environ. Sci. Eng. 2018, 12, 7. [CrossRef]

58. Cao, C.; Li, C.; Yang, Q.; Liu, Y.; Qu, T. A novel multi-objective programming model of relief distribution for sustainable disaster supply chain in large-scale natural disasters. J. Clean. Prod. 2018, 174, 1422-1435. [CrossRef]

59. Zhao, Y.; Li, D.; Pan, L.Q. Cooperation or competition: An evolutionary game study between commercial banks and big data-based E-commerce financial institutions in China. Discret. Dyn. Nat. Soc. 2015, 2015, 1-8. [CrossRef]

60. Behl, A.; Dutta, P.; Lessmann, S.; Dwivedi, Y.K.; Kar, S. A conceptual framework for the adoption of big data analytics by E-commerce startups: A case-based approach. Inf. Syst. E-Bus. Manag. 2019, 17, 285-318. [CrossRef]

61. Zhang, B.; Du, Z.; Wang, B.; Wang, Z. Motivation and challenges for E-commerce in e-waste recycling under "Big data" context: A perspective from household willingness in China. Technol. Forecast. Soc. Chang. 2019, 144, 436-444. [CrossRef]

62. Zhou, H.J.; Sun, G.; Fu, S. A scalable approach for fraud detection in online E-commerce transactions with big data analytics. Comput. Mater. Contin. 2019, 60, 179-192. [CrossRef]

63. Liu, X.; Liu, X.; Luo, X.; Fu, H.; Wang, M.; Li, L. Impact of different policy instruments on diffusing energy consumption monitoring technology in public buildings: Evidence from Xi'an, China. J. Clean. Prod. 2020, 251, 119693. [CrossRef]

64. Wu, J.; Shi, J.; Li, T.Y. A novel image encryption approach based on a hyperchaotic system, pixel-level filtering with variable kernels, and DNA-level diffusion. Entropy 2020, 22, 5. [CrossRef]

(C) 2020 by the authors. Licensee MDPI, Basel, Switzerland. This article is an open access article distributed under the terms and conditions of the Creative Commons Attribution (CC BY) license (http://creativecommons.org/licenses/by/4.0/). 